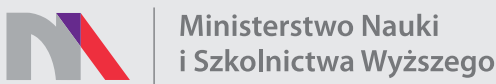

Digitalizacja archiwalnych numerów czasopisma naukowego Analecta Cracoviensia 1-24 (1969-1992) i ich publikacja w otwartym dostępie - zadanie finansowane w ramach umowy 672/P-DUN/2017 ze środków Ministra Nauki i Szkolnictwa Wyższego przeznaczonych na działalność upowszechniającą naukę

\title{
PROCES TWORZENIA POJECIA BYTU A KWESTIA ISTNIENIA BOGA
}

Metafizyka jest taką, jakim pojęciem bytu operuje. Jeżeli zważyć, że pojęcie bytu stanowi przedmiot formalny metafizyki, zatem że w jego właśnie aspekcie dokonuje się wyjaśnianie rzeczywistości - to teza, iż od przyjętego pojęcia bytu zależy kształt metafizyki ${ }^{1}$, nie potrzebuje dalszych uzasadnień ${ }^{2}$.

Wskazuje się na dwa zabiegi mające prowadzić do utworzenia pojęcia bytu: proces abstrakcji i proces separacji. Niestety terminologia $\mathrm{w}$. tej sprawie nie jest ujednolicona. Ten sam zabieg przez jednych autorów nazywany jest abstrakcją, przez innych separacją, czasami różne zabiegi opatrywane są tą samą nazwą. Niektórzy utożsamiają separację $z$ trzecim stopniem abstrakcji treściowej ${ }^{3}$. Nie wnikając $w$ owe terminologiczne powikłania, chciałbym rozważyć, na jakiej drodze należy formować pojęcie bytu, jeśli stawia się przed metafizyką następujące postulaty: (1) metafizyka ma być wiedzą filozoficzną o rzeczywistości; (2) przedmiotem badań metafizyki winien być cały zakres istniejących realnie konkretów; (3) metafizyka ma ująć nie tylko jakąś stronę rzeczywistości, ale całą jej głębię, całą zawartość bytową; (4) aspekt badania rzeczywistości winien być neutralny, tzn. taki, który nie wprowadzałby w rzeczywistość żadnyc'n myślowych prekoncepcji. Wymienione

1 Zob. np. M. A. Krąpiec, Metafizyka. Zarys podstawowych zagadnień, Poznań $1966,111$.

2 Dlatego musi wydać się dziwne pominięcie kwestii tworzenia pojęcia bytu w wielu monografiach traktujących o bycie lub metodzie metafizyki. Zwraca na to uwagę R. W. Schmidt, L'emploi de la séparation en métaphysique, „Revue Philosophique de Louvain" 58 (1960) 375.

3 ,Some authors call separation ,abstrakcion in the wide sense" or ,the third degree of abstraction". These expressions are confusing at best; ... at worst, they betray abstractionism and essentialism".: G. P. Klubertanz, Introduction to the philosophy of being. New York 1955, 42 (przyp. 30). Uwagę Klubertanza można odnieść na przykład do Maritaina; Zob.. J. Maritain, Court traité de l'existence et dt l'existant, Paris 1947, $49 \mathrm{nn}$. 
póstulaty są typowe dla tomizmu egzystencjalnego ${ }^{4}$. Stąd zadanie artykułu można sprecyzować jako próbę określenia, jakim pojęcie bytu winno się operować w egzystencjalnej teorii bytu.

Biorąc pod uwagę powyższą listę wymogów stawianych przed metafizyką trzeba stwierdzić, że pojęcie bytu winno odpowiednio być: (ad 1) pojęciem egzystencjalnie doniosłym; (ad 2) pojęciem transcendentalnym, tak by wszystkie istniejące byty były jego desygnatami; (ad 3) nie powinno nic ,z bytu” pomijać; (ad 4) nie może przesądzać, jaka powinna być rzecz, jeśli ma istnieć.

Abstrakcja, jeśli się ją rozumie jako zabieg, który „,spośród cech złączonych ze sobą izoluje sztucznie jedne od drugich" ", nie może doprowadzić do utworzenia takiego pojęcia bytu, które spełniałoby wymienione wymagania, ponieważ uzyskane na drodze abstrakcji pojęcie: (a) nie ujmuje istnienia bytu, lecz tylko jego treść; (b) jest, przy najszerszym zakresie, ,puste treściowo"; (c) pomija cały szereg bytowych aspektów; (d) akcentuje, na skutek swej wybiórczości, pewną treść ${ }^{6}$.

Uznając nieskuteczność rozumianego tak procesu abstrakcji dla skonstruowania pojęcia bytu, należy z kolei zbadać, czy zadanie to spełnia proces separacji. (Kwestia, czy abstrakcja inaczej pojęta nie okazałaby się do tego celu przydatna, nie mieści się w tematyce artykułu). Bardzo ogólną wzmiankę o separacji jako drugiej operacji intelektu, polegającej na łączeniu i dzieleniu i charakterystycznej właśnie dla metafizyki, czyni już św. Tomasz z Akwinu 7. Tekst Tomasza poddali współcześnie analizie: Régis, Geiger, Blanché, Maurer, Schmidt, Robert, Renard, Klubertanz, Krąpiec, opowiadając się za zabiegiem separacji jako właściwym dla formowania pojęcia bytu ${ }^{8}$. Nie wszystkim jednak wymienionym myślicielom powiodło się uzyskanie takiego pojęcia bytu, które odznaczałoby się określonymi wyżej czterema rysami charakterystycznymi. Ponieważ sądzę, że najbliższym tego celu był Krąpiec, dlatego też jego

4 Por. M. A. Krąpiec, Metafizyka, 48 n. Powyższa lista postulatów nie jest kompletna. Wyliczono tylko te, które sterują operacją tworzenia pojęcia bytu.

5 K. Kłósak, Stosunek filozofii przyrody do metafizyki $w$ ujęciu wspótczesnych neoscholastyków polskich, „Roczniki Filozoficzne KUL” (1965) z. 3, 15. (Zob. też s. 18-20).

6 Zob. M. A. Krąpiec, Metafizyka, 85. Por. tenże, Transcendentalia $i$ uniwersalia, „Roczniki Filozoficzne KUL” 7 (1960) z. 1, 18. Zresztą już Geiger sądził, że: ,.... ce dont on voudrait l' abstraire est de l'être, et l'aspect le plus important de l'analyse est précisement la découverte de l'inutilité de 1' abstraction.": L. B. Geiger, La participation dans la philosophie de S. Thomas d'Aquin, Paris 1942, 316. Zob. też tenże, Abstraction et séparation d' après saint Thomas, „Revue des Sciences Philossophiques et Théologiques" 31 (1947) 3-40.

7 Zob. In Boeth. de Trinit. $5,3$.

8 Literaturę dotyczącą separacji jako procesu tworzenia pojęcia bytu podaje R. W. Schmidt, art. cyt., $374 \mathrm{n}$. Do wymienionych tam pozycji należałoby dodać następujące: M. A. Krąpieic, Metafizyka, 86-93; K. Kłósak, art. cyt., 20-24; A. B. Stępień, Wprowadzenie do metafizyki, Kraków 1964, 51-58; Z. J. Zdybicka, Partycypacja bytu, Lublin 1972, 121-129. 
ujęcie separacji niech posłuży za punkt wyjścia analiz. W skrócie można je przestawić następująco:

Proces tworzenia pojęcia bytu rozpoczyna się wydaniem szeregu sądów egzystencjalnych stwiendzających istnienie wielu bytowych konkretów. Sądy te ogarniają cały szereg bytów, stwierdzają istnienie bytów materialnych, niematerialnych, substancjalnych, przypadłościowych, naturalnych i sztucznie skonstruowanych. Zawartość owych sądów poddaje się następnie analizie przy pomocy sądów orzecznilkowych negatywnych. Celem tego zabiegu jest uchwycenie koniecznych warunków bycia bytem. Zestawienie szeregu sądów egzystencjalnych przekonuje, że o istnieniu czegokolwiek nie decyduje żaden zespół treści. Nie da się wskazać takiej treści, która w sposób konieczny musiałaby być zrealizowana, która musiałaby istnieć. Dwa elementy ujęte w sądach egzystencjalnych (treść i istnienie) łączy się ze sobą w sposób niekonieczny, ponieważ dostrzegamy owe elementy $w$ coraz to innych połaczeniach. Elementy te dadzą się od siebie ,separować”. Nie jest konieczne dla bycia bytem posiadanie np. cechy ,x", bo istnieją przedmioty, które tej cechy nie posiadają. Aby istnieć, nie potrzeba być bytem danej kategorii, ponieważ istnieją przedmioty innych kategorii. Bytowość nie jest zatem związana $\mathrm{z}$ jakąś konkretną treścią ani $\mathrm{z}$ jakąś formą bytowania. Jedynym elementem, który w sposób konieczny towarzyszy w bycie zmiennej w każdym poszczególnym wypadku treści, jest istnienie. Być zatem bytem, to znaczy być jakąś zdeterminowaną, istniejącą treścią. Jeśli tak, to pojęcie bytu musi zawierać w sobie dwa elementy przyporzadkowane do siebie: treść i istnienie. Stąd jest ono nie tyle pojęciem, co raczej sądem tożsamościowym ujawniającym poprzez swój podmiot i orzecznik składowe elementy bytu. Sąd ten można zapisać w postaci ,to, co jest — istnieje". Ponieważ jednak aspekt esencjalny bytu nie utożsamia się całkowicie $\mathrm{z}$ aspektem egzystencjalnym, dlatego Krąpiec posługuje się zwrotem ,tożsamość relatywna" 9 .

W stosunku do tak lub podobnie zarysowanego procesu separacji wysuwano liczne zastrzeżenia, wskazywano na pewne niejasności. T. Rutowski zwracał uwagę, że czynności, jakich trzeba dokonać, aby otrzymać pojęcie bytu, implikują prawdziwość pierwszych zasad, zwłaszcza tożsamości i niesprzeczności. Powstaje pytanie, czy nie mamy do czynienia z błędnym kołem? „Dochodząc bowiem do pierwszych zasad rozumianych ontologicznie posługujemy się regułami metodologicznymi, które uznaje się na podstawie właśnie pierwszych zasad"10. A. B. Stępień podkreśla, że dokonując separacji opieramy się na danych empi-

9 Zob. M. A. Krapiec, Metafizyka, 99.

10 T. Rutowski, Czy tak zwane pierwsze zasady tomistycznej filozofii bytu sq naprawde pierwsze, ,Studia Philosophiae Christianae" 3 (1967) $\mathrm{nr}$ 2, 228. 
rycznych, zaitem akceptujemy wartość poznawczą pewnych spostrzeżeń. Ten problem łączy się z kwestią rozgraniczenia kompetencji metafizyki i teorii poznania ${ }^{11}$. Według $K$. Kłósaka trzeba już wcześniej dysponować, uzyskanym na innej drodze, pojęciem bytu, by móc przy pomocy sądów orzecznikowych stwierdzić, że byt jako taki, nie jest koniecznie związany z jakąś kategorią bytowania. Przy pomocy tych sądów można wyodrębnić myślowo tylko to, co jest oddzielone od siebie w rzeczywistości, a bytowość nie jest oddzielona od konkretu rzeczy ${ }^{12}$. Z wypowiedzi Kłósaka wynika także wniosek, że ponieważ proces separacji prowadzi dopiero do utworzenia pojęcia bytu - to nie należy w trakcie tego procesu określać, co jest, a co nie jest bytem. Precyzyjniej jest, tak postępuje np. Stępień w cytowanym dziele, wskazywać, co jest lub nie jest warunkiem niezbędnym istnienia czegoś.

Dyskutuje się, czy dla utworzenia pojęcia bytu konieczna jest znajomość istnienia bytów niematerialnych. Za taką koniecznością opowiedział się w cytowanych pracach pierwszy teoretyk separacji Geiger. Jego stanowisko podtrzymują J. Kalinowski i M. Jaworski ${ }^{13}$. Opis zabiegu separacji zamieszczony w Metafizyce wskazywałby, że także Krąpiec postępuje w tej kwestii za Geigerem. Gdzie indziej jednak polski tomista uważa - nie eksplikując zresztą szerzej swojego poglądu — że do utworzenia pojęcia bytu wystarcza stwierdzić istnienie wielu bytów ${ }^{14}$. Sprawa nie wydaje się bagatelna, jeśli bowiem uznać konieczność znajomości istnienia bytów niematerialnych już podczas tworzenia pojęcia bytu - to trzeba by na tym etapie metafizyki korzystać $z$ tez, które uzasadnia się dopieno w końcowych partiach metafizyki ogólnej lub w antropologii filozoficznej. Taki stan rzeczy budzi niepokój, mimo że przyjmuje się, iż metafizyka jest zbiorem pryncypiów uzasadnianych bezpośrednio ${ }^{15}$. Kwestię próbuje rozwiązać Klubertanz. Jego zdaniem nie potrzeba wiedzieć, tworząc pojęcie bytu, że istnieją rzeczy materialne. Wystarczy tylko stwierdzić, że nie materia decyduje o ich istnieniu. Dostrzegamy, że być realnym to nie to samo, co być materialnym, ponieważ materia jest podległa determinacji, a nie jest zasadą aktualności i determinacji 16. Tak argumentując, Klubertanz używa jednak terminu, materia' nie w jego znaczeniu potocznym (to co oglądowe, mierzalne, prze-

11 Zab. A. B. Stępień, dz. cyt., 55.

12 Zob. K. Kłósak, Sprostowania w sprawie mojej polemiki z O. Prof. A. Krąpcem O. P., „Znak” 124 (1964) $1266 \mathrm{n}$.

13 Zob. J. Kalinowski, Ontologia czy aitiologia, „Znak” 111 (1963) 1074 n; Por. M. Jaworski, Zagadnienie reinterpretacji punktu wyjścia filozoficznego poznania Boga, [w:] Studia $z$ filozofii Boga, t. 2, Warszawa 1973, 172-175.

14 Zob. M. A. Krąpiec, O rozumienie metafizyki, ,Znak” 111 (1963) 1082.

15 Zob. S. Kamiński, M. A. Krąpiec, Z teoriii $i$ metodologii metafizyki, Lublin $1962,253$.

16 Zob. G. P. Klubertanz, dz. cyt., 43, 48. 
strzenne i czasowe), ale w znaczeniu filozoficznym. W ten sposób także zakłada późniejsze partie metafizyki, wskutek czego nie dostrzega rozwiązania interesującej nas kwestii.

Do powyższych uwag czynionych pod adresem separacji można jeszcze dołączyć pytanie, czy tworząc pojęcie bytu nie należałoby „separować" nie tylko od indywidualności i gatunkowości, ale także od sposobów istnienia. Przecież rozstrzygnięcie kwestii, czy wszystkie kategorie bytów (np. byty materialne, matematyczne, dzieła sztuki) istnieją w jednakowy sposób, jest na tym etapie rozważań niemożliwe. Zresztą sam Krąpiec pisze: „Byt bowiem jako taki nie jest nierozłącznie zrośnięty z jakąś kategorią, czyli sposobem istnienia" ${ }^{17 .}$ W tej sytuacji trzeba by zmodyfikować wniosek końcowy separacji: aby coś było bytem, musi zawierać dwa elementy - jakąś treść i jakieś istnienie. Nie tylko żadna kwalifikacja treściowa, ale także żaden sposób istnienia nie łączy się w sposób konieczny z bytem. Jeżeli tak, to nie można by także już teraz rozstrzygać, który z wymienionych elementów gra wiodącą rolę $w$ bycie. Obecność obu jest konieczna, ale nie jest niezbędne, by w bycie realizowała się taka a nie inna treść, ani takie a nie inne istnienie.

Tak przedstawia się, w ogólnych zarysach, stan badań nad procesem separacji. Rzuca się przede wszystkim w oczy, że nie zostało dotychczas sprecyzowane, jaki zestaw sądów egzystencjalnych jest potrzebny, by analiza ich zawartości mogła doprowadzić do utworzenia pojęcia bytu. Dzieje się tak być może na skutek przesadnego eksponowania roli intuicji intelektualnej w separacji 18. Jeżeli intuicja jest poznaniem bezpośrednim, dokonującym się niedyskursywnie, to mogłoby się wydawać, że uwalnia nas ona od potrzeby przeprowadzania dokładnych analiz. Tymczasem „Akty intuicji intelektualnej, które w swej najgłębszej naturze są jakimś bezpośrednim oglądem, wizją, nie są jednak samorzutnym widzeniem natury rzeczy, lecz wynikiem żmudnego, długotrwalego dociekania poprzez skomplikowane procesy abstrakcji, analizy i dyskursu. One jakby warunkują intuicyjne dojrzenie prawdy w odpowiednio wskazanej rzeczywistoścí. Mają za zadanie dobrać i uporządkować wszystkie dane potrzebne dla aktu intuicji, wskazać jakby dla niego drogę" ${ }^{19}$. Jeżeli tak, to nie wystarczy — przy formowaniu pojęcia bytu -

17 M. A. Krapiec, Teoria analogii bytu, Lublin 1959, 139.

18 Oczywiste jest, że końcorwy wniosek wieńczący zabieg tworzenia pojęcia bytu nie może być uzyskany przy pomocy indukcji niezupełnej - byłby wtedy jedynie prawdopodobny. Dlatego mówi się o wglądzie intelektualnym lub, jak chcą niektórzy, o intuicyjnym dostrzeganiu tego, co jest konieczne, by coś istniało. Maritain pisał: ,... à la racine de la connalissance métaphysique il met l'intuition intellectuelle de cette mystérieuse réalité qui se dissimule sous le mot le plus commun et le plus banal de notre langage, le mot ,être" (Court traité de l'existence et de l'existant, 37).

19 Z. J. Zdybicka, O intuicji $w$ filozofii, ,Roczniki Filozoficzne KUL” 12 (1964) z. $1,128$. 
wydanie kilku sądów egzystencjalnych i powołanie się na intuicję, by uzyskać końcowy wynik. Ewentualne dalsze przykłady traktowane byłylby $w$ takiej sytuacji czysto dydaktycznie. Miałyby jedynie pokazać, że nie ma sensu postępować dalej, ponieważ nie wpłynie to na zmianę uzyskanego wyniku. Wydaje się jednak, że pierwsze dwa etapy separacji muszą stanowić bardzo dokładne przygotowanie dla intuicyjnego uchwycenia warunków koniecznych bycia bytem.

Ponieważ metoda analizowania zawartości sądów egzystencjalnych stosowana $\mathrm{w}$ drugim etapie separacji wydaje się tyleż prosta, co skuteczna, dlatego zagadnienie sprowadza się do określenia, jakie sądy egzystencjalne należy zestawić w pierwszym etapie, aby można było uformować pojęcie bytu. Wydaje się, że na odnośnej liście nie mogą się znaleźć sądy egzystencjalne pośrednie. Do sądów tych dochodzi się przecież $\mathrm{w}$ trakcie wyjaśniania rzeczywistości właśnie w aspekcie pojęcia bytu. Ono jest pierwszym pojęciem teoretycznym metafizyki, proces jego tworzenia nie należy jeszcze do systemu, jest etapem wstępnym prowadzącym do ukonstytuowania się tegoż. Ô etap wstępny powinien być wolny od wprowadzania doń tez systemu, a co za tym idzie, także pojęć teoretycznych specyficznych dla danego systemu.

Uwzględniając powyższe, pozostaje rozważyć, jakiego typu sądy egzystencjalne bezpośrednie należy zestawić w pierwszym etapie separacji. Da się wyróżnić trzy typy sądów egzystencjalnych bezpośrednich, biorąc za podstawę stopień uwyraźnienia treści: (1) sądy egzystencjalne typu ,coś jest" — zatem takie, w których treść przedmiotu, jakiego istnienie stwierdzamy, nie jest $\mathrm{w}$ żadnym stopniu uwyraźniona; (2) sądy egzystencjalne, w kztórych określa się, jaki jest przedmiot, którego istnienie stwierdzamy. Określenie to dokonuje się poprzez wyliczenie - zwykle najbardziej odznaczających się - cech przedmiotu; (3) sądy egzystencjalne, w których treść została już opracowana przez intelekt czynny, zatem takie, w których na miejscu podmiotu figuruje pojęcie ${ }^{20}$.

Oczywiste jest, że aby móc dokonywać czynności oddzielania, trzeba mieć co oddzielać, stąd $w$ grę mogą wchodzić tylko te sądy egzystencjalne, w których treść jest już w jakimś stopniu uwyraźniona. Sprawia to, że sądy egzystencjalne pierwszego typu są dla procesu tworzenia pojęcia bytu bezużyteczne. Nie ulega natomiast wątpliwości, że w procesie separacji można i trzelba posługiwać się sądami egzystencjalnymi drugiego typu. Czy jednak tylko nimi? Tak wydaje się sądzić Zdybicka, skoro pisze, że do wykrycia istotnych elementów bytu wystarcza analiza tych sądów egzystencjalnych, w których podmiotem jest zawsze nazwa

20 Zoib. B. Bakies, Sądy egzystencjalne a punkt wyjścia metafizyki, „Studia Philosophiae Christianae" 14 (1978) nr 1, 11. 
jednostkowego przedmiotu ${ }^{21}$. Nie widać jednak, jak przy pomocy wyłącznie tego rodzaju sądów można by uzyskać przekroczenie kategorialności, a nie tylko indywidualności. Po to, by przygotować intuicyjne zrozumienie, że bytowość nie jest koniecznie związana $\mathrm{z}$ jakąś kategorią rzeczy, trzeba wydać sądy egzystencjalne trzeciego typu. Inaczej, nawet wyliczając takie istniejące indywidua, które należą do różnych kategorii, ale nie uświadamiając sobie owej przynależności - nie można by stwierdzić, że kategorialność została przekroczona.

Z powyższego wynika, że uwzględnienie sądów egzystencjalnych trzeciego typu jest $\mathrm{w}$ procesie separacji konieczne. Jaka liczba tych sądów jest niezbędna do stwierdzenia, że bytowość nie jest związana w sposób konieczny z żadną kategorią bytowania? Aby odpowiedzieć na to pytanie, trzeba pamiętać, że wniosek separacji, c'nociaż sformułowany przy pomocy intuicji intelektualnej, nie może zawierać czegoś, co nie zawierało się $w$ danych przygotowujących akt intuicji. Kiedy się poza owe dane wykracza? Wydaje się, że wtedy, gdy to, na co rozciągamy wniosek separacji, nie stanowi jednorodnej ( $\mathrm{z}$ pewnego punktu widzenia) sfery przedmiotów $\mathrm{z}$ przedmiotami, których istnienie zostało wyraźnie stwierdzone $w$ pierwszym etapie separacji. Dlatego nie odczuwamy oporów, gdy - po stwierdzeniu, iż do bycia bytem nie potrzeba być kamieniem, kozą, czy człowiekiem - przyjmujemy, że bytowanie nie jest w sposób konieczny związane z ,krzesłowatością”, czy „rybowatością”. I przyjmujemy to już bez stwierdzenia istnienia krzesła i ryby - właśnie na mocy intelektualnego dostrzeżenia, że owe przedmioty stanowią $z$ przedmiotami, których istnienie zostało wyraźnie stwierdzone, jednorodną kategorię. Jeżeli zatem dyskutuje się, czy można wniosek separacji rozciągnąć na przedmioty niematerialne - nie wydając na pierwszym etapie separacji sądów egzystencjalnych stwierdzających istnienie przedmiotów niematerialnych - to dzieje się tak dlatego, ponieważ istnieją wątpliwości, czy można przedmioty materialne i niematerialne zaliczyć do jednorodnej kategorii. Rozstrzygnięcie, czy są to wątpliwości słuszne, mogłoby zapaść po dokonaniu bardziej gruntownej analizy procesu separacji 22.

Analizy takiej nie będę $\mathrm{w}$ niniejszym artykule przeprowadzał, ponieważ $-\mathrm{z}$ innych racji - uważam ją za zbędną. Sądzę, mianowicie, że choćby nawet udało się $\mathrm{w}$ procesie separacji uzyskać przekroczenie kategorii bytów materialnych, to nie może się powieść przekroczenie kategorii bytów przygodnych ${ }^{23}$, wskutek czego przy pomocy procesu separacji

21 Zob. Z. J. Zdybiicka, Partycypacja bytu, 123.

22 Analiza taka winna także zawierać dyskusję, czy do desygnatów transcendentalnego pojęcia bytu należa byty idiealne $i$ intencjonalne. Zob. w tej sprawie K. Kłósak, Koncepcja bytu a filozofia Boga, [w:] Studia $z$ filozofii Boga, t. 3, Warszawa 1977, 12-14.

23 Byty przygadne także stanowią pewną kategorię bytów, wprawdzie bardzo 
można uzyskać jedynie pojęcie bytu przygodnego. Tak jak bez sądów egzystencjalnych trzeciego typu nie uzyska się przekroczenia indywidualności, tak też nie można wykroczyć poza byty przygodne - jeśli na liśoie sądów egzystencjalnych, których zawartość analizujemy, nie znajdzie się sąd egzystencjalny pośredni „Bóg istnieje”. Dane przygotowujące akt intuicji uprawniają bowiem tylko do wyciągnięcia wniosku, że w bycrie istnienie może łączyć się $\mathrm{z}$ dowolnym ulkładem treści. Nie uprawniają do twierdzenia, iż żadna treść nie jest potrzebna do tego, aby być bytem, że może istnieć byt nie posiadający w ogóle treści. Zdybicka pisze: ,Analiza struktury sądu egzystencjalnego oraz faktu, że sądów tych jest wiele, prowadziłaby do... wyróżnienia w stwierdzonych bytach tego, co kategorialne, i tego, co transcendentalne. Kategorialność wyraża się w rozmaitości zaszeregowania podmiotów. Transcendentalność natomiast ujawnia powtarzające się orzeczenie, które w przysługiwaniu rozmaitym podmiotom przekracza ich typy" 24 . Otóż, aby mieć podstawę do przekroczenia danej kategorii, trzeba wskazać przynajmniej jeden wypadek, w którym orzeczenie sądu egzystencjalnego przysługuje takiemu bytowi, który do owej kategorii nie należy. Jeżeli chce się przelkroczyć kategorię przygodności, to trzeba wskazać na taki realnie istniejący byt, który bytem przygodnym nie jest - zatem na Boga.

Powyższe rozważania potwierdza fakt, że wszyscy teoretycy separacji, określając zawartość ${ }^{25}$ pojęcia bytu, wskazywali, że należy do niej istnienie i jakaś treść. Jeżeli jednak tak, to uzyskane zostało nie transcendentalne pojęcie bytu, lecz pojęcie, którego desygnatem są wszystkie i tylko - byty przygodne. Jest tak dlatego, ponieważ uznając, że każdy bez wyjątku byt jest złożony $\mathrm{z}$ istnienia i treści, trzeba by konsekwentnie uznać ograniczoność za transcendentalną właściwość bytu, każdy bowiem byt zawierałby element potencjalny, ograniczający (ukwalifikowanie treściowe). Jest to jednak fałszem w przypadku jednego bytu - Boga ${ }^{26}$. Aby uzyskać transcendentalne pojęcie bytu należy ująć w jego zawartości tylko to, co decyduje o realnym bytowaniu czegoś, a nie to, co decyduje, że owo coś istnieje w jakiś sposób. Ten ostatni przypaldelk zachodzi wtedy, gdy powie się, że warunkiem bycia jest istnieć i posiadać

specyficzną, ponieważ należą do niej wszystkie byty oprócz jedmego, ale jednak kategorię.

24 Z.J. Zdybicka, Partycypacja bytu, 123.

25 Zdybicka, aby nie mylić czynników konstytutywnych bytu z istotnymi kwalifikacjami treściowymi, używając na oznaiczenie tych pierwszych wyrażeń „treść bytu" czy "istota bytu" - bierze je w culdzysłów. (Zob. Z. J. Zdybicka, Partycypacja bytu, 125). Analogicznie należy, pisząc o ,treści" pojęcia bytu, ujjmować słowo 'treść' w cudzysłów. Lepiej jednak posługiwać się w tym wypadku terminem zawartość.

26 Dlattego nie można zgodzić się z następującym sitanowiskiem: „Element potencjalny bytu jest treścią, aktualny zaś istnieniem. Dlatego pojęcie bytu wyrażające istote $i$ istnienie dotyczy wszelkich aktualnych i możliwych realnie bytów, stąd weryfikuje się w każdym konkrecie". (M. A. Krąpiec, Metafizyka, 120). 
jakąś treść. Określa się wtedy sposób, w jaki byty istnieją - a jest to właśnie przygodny sposób bytowania ${ }^{27}$.

Dlaczegóż więc zadanie uzyskania transcendentalnego pojęcia bytu nie zostało w pełni rozwiązane? Stawiamy to pytanie mimo świadomości, ,...że materialność jest tylko modyfikacją realności rzeczy, że więc podstawowa jest realność, którą coś modyfikuje. Tym czynnikiem modyfikującym są treści" 28, mimo wiedzy, że „są byty" „zbudowane” $\mathrm{z}$ istnienia $\mathrm{i}$ treści zawierających także materię. A Bóg jest po prostu inaczej „zbudowany”. Jest samym ,istnieniem” ${ }^{29}$; wreszcie mimo stwierdzenia, że za tworzywo bytu trzeba uznać to, czego odrzucenie unicestwia byt ${ }^{30}$. Wydaje się przecież, że odrzucenie treści nie unicestwia bytu. Jej obecność nie jest koniecznym warunkiem bytowania. Gogacz jednakże pisze: „Gdy się jednak rozstrzyga, że coś jest realne, odkrywa się jednocześnie czynnik urealniający i czynnik urealniany" ${ }^{31}$. Ale stawiając tak sprawę utożsamia się bycie czymś realnym z byciem czymś przygodnym, stawia się znak równości między pytaniem o strukturę bytu $z$ pytaniem o powód jego realności. Gdzie następuje przesunięcie $z$ poszukiwania tego, co urealnia byt, na poszukiwanie struktury tego, co przygodne? Powód tkwi może w poglądzie, według którego w poszukiwaniu czynników bytowych czyniących coś realnym bytem należy posłużyć się ,zabiegiem eliminacji tego, co nie jest konieczne, aby dany byt był realnie tym bytem" 32 . Zacytowany zwrot byłby w pełni słuszny, gdyrby nie jedno zbędne słowo - „tym". Jego użycie jest powtórzeniem błędu, jaki popełnił Platon, czyniąc - w pewnej mierze - krok wstecz w stosunku do stanowiska Parmenidesa. Założyciel Akademii przestał mianowicie pytać o to, co jest by t em w ogóle, a zapytał, co jest tym bytem, co jest bytem danej kategorii. W odpowiedzi na takie pytanie powstała teoria idei. Pytając jednak o warunki konieczne do tego, by coś było bytem, trzeba w odpowiedzi wskazać na czynniki istotne dla jakiejś kategorii bytowania. Jeżeli wyliczając czynniki konieczne dla byto-

27 Tę samą myśl, chociaż inaczej wyrażoną, znajdujemy u Maritaina, według ustórego na pojęcie bytu składają się właściwości przysługujące bytowi tylko ze względu na to, że jest bytem. (J. Maritain, Sept leçons sur l'être et les premiers principes de la raison spéculative, Paris 1934, 71 n.). Nie przeszkadza to Maritainowi, jak wszystkim tomistom egzystencjalnym, umieszczać w zawartości pojęcia bytu tak treści, jak istnienia. (Zob. tamże, 27; tenże, Antimoderne, Paris 1922, 161; tenże, Court traité de l'existence et de l'existant, 60). Omówienie koncepcji bytu Maritaina zolb. K. Kłósak, Próba uwspółcześnienia Tomaszowej argumentacji $z a$ istnieniem Boga z przyczynowości sprawczej, [w:] Studia $z$ filozofii Boga, t. 2, Warszawa 1973, 206-208; E. Morawiec, Rola intuicji w przyjmowaniu pierwszych założeń $w$ metafizyce ogólnej u J. Maritaina, Warszawa 1974, 61-78.

28 M. Gogacz, Istnieć $i$ poznawać, Warszawa 1976, 81.

29 Tamże, 82.

30. Zoib. tamże, 52.

31 Tamże, 106.

32 Tamże, 53. 
wania, wskazuję na treść i istnienie, to znaczy, że zadałem sobie pytanie „co jest tym bytem” (a nie pytanie, „co jest bytem w ogóle”), przez ,tym” rozumiejąc byt przygodny; kategorię bytowania przygodnego.

Zatrzymałem się dłużej przy tekstach Gogacza dlatego, że pozycja, z której zostały zaczerpnięte, jest ostatnią, która porusza interesujące nas zagadnienie, zatem dobrze ilustruje fakt, że zarysowane wyżej poglądy tomistów egzystencjalnych na omawianą kwestię nie uległy zmianie.

W ramach egzystencjalnej teorii bytu dokonany został bardzo poważny krok w kierunku ukazania właściwego wymiaru problemu istnienia Boga. Dostrzeżono, że ,wykazanie istnienia Absolutu musi być oparte na prawach, które obowiązują świat, jak i to, co w stosunku do niego transcendentne. Te konieczne prawa nie są dane ,a priori”, ale są „konsekwencją" natury bytu" 33. Jeżeli jednak obowiązujące prawa są ,konsekwencją" natury bytu, a nie dociera się do natury bytu jako takiego, lecz jedynie do natury bytu przygodnego, to i uzyskane prawa będą stosowały się tylko do bytów przygodnych (świata), a nie do bytu transcendentnego wobec świata - Boga. I rzeczywiście tę konsekwencję dostrzegamy u Krąpca. Nazywa on pojęcie bytu, jakie uzyskał na drodze separacji, zasadą tożsamości relatywnej ${ }^{34}$. Zasada ta, jak widać, nie stosuje się do Boga, w którym zachodzi tożsamość absolutna.

Ujmując rzecz od innej strony: filozofia, jak każda nauka, nie może wykroczyć w rozważaniach poza swój przedmiot. Specyfiką wyjaśnienia w metafizyce jest przekraczanie dziedziny faktów danych ${ }^{35}$. Wyjaśniany stan rzeczy domaga się często wskazania, jako na swoją rację, na taki stan rzeczy, który nie jest i nie może być dany w bezpośrednim doświadczeniu. Operowanie transcendentalnym pojęciem bytu sprawia, że jakiekolwiek przedimioty ukażą się (w wyżej wskazany sposób) w polu widzenia metafizyka, to wszystkie one będą należały do przedmiotu materialnego metafizylki. Możność mówienia o Bogu, jaka się w ten sposób otwiera, jest tylko (choć najbardziej nas tu interesującym) przykładem korzyści płynącej z nakreślonej specyfiki metafizyki. Jeżeli jednak utworzy się pojęcie bytu, którego deșygnatami są wyłącznie byty przygodne, to Bóg nie jest i nie może stać się przedmiotem metafizyki.

$\mathrm{Z}$ faktu uzyskania poprzez proces separacji pojęcia bytu przygodnego, a nie transicendentalnego, wynikają dwie niedogodności: (1) w argumentacji na istnienie Boga najpierw uznaje się, że wszystkie były są złożone $z$ istnienia $i$ jakiegoś ukwalifikowania treściowego (skoro nazywa się transcendentalnym takie pojęcie bytu, w którego zawartości znajduje

s3 S. Kamiński, Z. J. Zdyibilcka, O sposobie poznania istnienia Boga, „Znaik” 120 (1964) 643 .

${ }_{34}$ Zob. M. A. Krappiec, Metafizyka, 99.

35 Zob. S. Kamiński, Wyjaśnianie $w$ metafizyce, „Róczniki Filozoficzne KUL” 14 1966) z. 1,62 . 
się istnienie i treść), potem zaś stwierdza się, że tego rodzaju byty nie tłumaczą swojego istnienia. Jako rację ich istnienia przyjmuje się byt nie posiadający ukwalifikowania treściowego (Czyste Istnienie). Jeśli tak, to teza o powszechnym i koniecznym złożeniu każdego bytu była fałszywa. Takie lub podobnie sformułowane zastrzeżenia wysuwa się zresztą często pod adresem tak skonstruowanej argumentacji. Bez względu na to, czy są one słuszne, lepiej unikać ich wysuwania, niż powodować konieczność wyjaśnień. Sprawa jest zresztą ogólniejsza. Zauważmy, że metafizyczne poszukiwania bytu (obojętne, czy przez byt rozumiano: liczbę, ideę, formę itp.) dążyły zawsze do wskazania na taki stan bytowy, który w sposób ostateczny wyjaśniał całą rzeczywistość, na ten rdzeń rzeczywistości, który nie domaga się już dalszego wyjaśniania. Natomiast, jeśli tworzy się pojęcie bytu, które wskazuje na takie byty jako na swoje desygnaty, których struktura nie tłumaczy się sama przez się - to mamy do czynienia z pewnym odejściem od stylu postępowania twórców metafizyki klasycznej. (2) Jeżeli pojęcie bytu uzyskane na drodze seperacji określić jako transcendentalne, a Bóg — z powodów wyżej wskazanych — nie jest desygnatem tego pojęcia, to trzeba uznać, że Bóg nie jest bytem. Byłaby to zatem jakaś forma plotynizmu. Wskazane niedogodności nie wystąpiłyby w przypadku dysponowania od początku metafizyki istotnie a nie pozornie transcendentalnym pojęciem bytu.

Wysuwając powyższe uwagi nie chcę twierdzić, że w tomizmie egzystencjalnym czyni się byty przygodne przedmiotem materialnym metafizyki ${ }^{36}$. Uważam tylko, że tomiści egzystencjalni używają terminu treść w znaczeniu, które detranscendentalizuje pojęcie bytu. Uważam także, że prezentowany w tomizmie egzystencjalnym sposób tworzenia pojęcia bytu nie ukazuje, jak - poszukując warunku bycia bytem ująć tylko ten jeden istotny warunek (istnienie), a ,pozbyć się" z zawartości pojęcia bytu warunków, które do bytowania jako takiego nie są konieczne. Chodzi szczególnie o posiadanie ukwalifikowania treściowego. Jeśli bowiem w zawartości pojęcia bytu znajdą się właściwości, które nie są konieczne do bytowania, to przedmioty tych właściwości nie posiadające znajdą się poza zakresem tak utworzonego pojęcia. Do ,istoty" Boga należy istnienie, do ,istoty" bytów przygodnych należy istnienie i jakieś ukwalifikowanie treściowe ${ }^{37}$. Jeśli chcemy, aby pojęcie bytu odnosiło się do wszystkich sposobów istniena tak przygodnego, jak i absolutnego - to w jego zawartości może się znaleźć tylko istnienie. Tylko

36 Krapiec na przyiklad silnie podkreśla w dyskusji z Kalinowskim, że przedmiotem metafizyki nie mogą być byty przygodne. (Zoib. M. A. Krąpiec, O rozumienie metafizyki, „Znak” 111, 1963, 1080).

37 Takie, jak powyżej, użycie terminu 'istota' nie powinno wzbudzać niepokoju, jeśli przyjmuje się, że rzecz może być poznana nie tylko na drodze poznania pojęciowego, ale także sądowego. 
ono bowiem jest koniecznym elementem bytu realnego. Wszystkie inne, poza istnieniem, o ile się w realnych bytach znajduje, jest dla bycia bytem ,przypadłością”. Ukwalifikowanie treściowe może się w realnym bycie znajdować lub nie. Esencjalizm, biorąc istotę (ukwalifikowanie treściowe) za ,istotę " bytu, wziął za istotne to, co przypadłościowe. W tomizmie egzystencjalnym dojrzano prymat istnienia $\mathrm{w}$ bycie, mimo to nie ono samo, lecz łącznie z treścią zostało uznane za element konstytutywny bytu jako takiego. Czy także w tej kwestii nie mamy do czynienia z pewnym odejściem od sposobu postępowania badawczego twórcy metafizyki - Arystotelesa? Stagiryta, badając byt dany w doświadczeniu doszedł do określenia podstawowej struktury bytu, na którą składa się, jego zdaniem, materia i forma. W tomizmie egzystencjalnym wskazuje się na treść i istnienie jako na podstawowe złożenie bytowe. W odpowiedzi na pytanie o to, co urealnia byt, Arystoteles wskazuje jednak nie na oba wykryte elementy w bycie, ale na formę. Aby w pojęciu bytu zawrzeć to, co istotne dla bycia bytem, trzeba wyabstrahować formę z materii. W tomizmie egzystencjalnym natomiast $w$ odpowiedzi na pytanie, co jest istotne dla bycia bytem, nie wskazuje się (uwzględniając zmianę koncepcji bytu) na istnienie, lecz na oba elementy strukturalne wykryte wcześniej - treść i istnienie. Oba te elementy zostaja umieszczone w zawartości pojęcia bytu. Dzieje się tak być może na skutek obawy, że ,coś z bytu" się pominie w utworzonym pojęciu bytu, uzyskując abstrakcjonistyczne a nie konkretystyczne pojęcie bytu ${ }^{38}$. Obawy te nie sa słuszne. Wskazujac na istnienie jako na jedyny konieczny warunek bytowania czegokolwiek, nie pomija się nic z bytu. Nie przesądza się przecież sposobu, w jaki coś ma istnieć (absolutny czy przygodny), zatem nie przesądza się także, czy istniejące przedmioty posiadają oprócz istnienia także treść czy nie.

Sądzę, że takie było stanowisko św. Tomasza z Akwinu, który pisał: „Cum in re duo sint, quidditas rei et esse ejus, his duobus respondet

$38 \mathrm{Na}$ temat abstrakcjonistycznego i konkretystycznego pojęcia bytu zob. K. Klósak, Próba uwspótcześnienia Tomaszowej argumentacji za istnieniem Boga z przyczynowości sprawczej, 206 n., 211 n.; tenże, Stosunek filozofii przyrody do metafizyki $w$ ujęciu wspótczesnych neoscholastyków polskich, 14 n., 18-20, 24; tenże, Koncepcja bytu a filozofia Boga, 11-16; M. Gogacz, Filozofia chrześcijańska w Polsce odrodzonej (1918-1968), ,,Studia Philosophiae Christianae” 5 (1969) nr 2, 70.

Analiza koncepcji Kłósaka nie mieści się w ramach niniejszego artykułu. Zwróćmy tylko uwagę, że wedlug krakowskiego myśliciela ,ujęcie abstrakcyjne i ogólne nie jesit [...] celem w sobbie, lecz służy do tego, by nie biorąc pod uwagę konkretnej strony przedmiotów realnych jako takiej, dotrzeć do tego, co w każdym $\mathrm{z}$ nich jest najbardziej zasadniczego, mianowicie do aspektu bycia czymś istniejacym realnie" (K. Kłósak, Koncepcja bytu a filozofia Boga, 14.). Jeśli tak, to abstrakcjonistyczne pojęcie bytowości jako formalnego przedmiotu metafizyki nie przeciwstawia się - być może - tak dalece założeniom egzystencjalnej teorii bytu, jak się nieraz sądzi. Zob. A. Wawrzyniak, Z. J. Zdybicka, Z dziejów metafizyki $i$ nauk pokrewnych na Katolickim Uniwersytecie Lubelskim (1918-1968), „Roczniki Filozoficzne KUL" 17 (1969) z. 1, 83. 
duplex operatio intellectus. Una quae dicitur a philosophis formatio, qua apprehendit quidditates rerum [...] Alia autem comprehendit esse rei $[\ldots]$ ]" ${ }^{39}$ oraz: „Prima autem operatio respicit ipsam naturam rei $[\ldots]$ Secunda vero operatio respicit ipsum esse rei [...]" ${ }^{40}$. Istnieje zatem operacja typowa dla metafizyki, w wyniku której umysł ujmuje samo istnienie rzeczy. Nie jest jednak tak ,that thing is at once grasped in a two fold way. It is attained according to its essence or nature by the act of conceptualization and, simultaneously, according to its being by the judgment. The intellect at the same time conceives „,what" the thing is and judges „that" it exists" ${ }^{41}$. Nie można ,od razu” i jednocześnie učnwycić, czym rzecz jest i że jest. Po pierwsze dlatego, że nie można wydać dwóch aktów poznawczych równocześnie. Po drugie, ponieważ zarówno, aby poznać, czym jest, jak i by poznać jej akt istnienia (o niego tu chodzi, nie zaś o fakt istnienia rzeczy ${ }^{42}$ ), trzeba dokonać właśnie całej operacji w pierwszym wypadku konceptulizacji, w drugim separacji.

Nie tylko zresztą u św. Tomasza, ale także u Martaina można znaleźć teksty idące po linif przedstawionej tu koncepcji. Wprawdzie, jak wyżej stwierdzono, ten ostatni nie odbiega od innych tomistów egzystencjalnych $\mathrm{w}$ poglądach na temat pojęcia bytu, umieszczając $\mathrm{w}$ jego zawartości istnienie oraz treść, Maritain wspomina jednak, że w pojęciu bytu można by ując tylko jeden element wspólny wszystkim rzeczom ${ }^{43}$. Nie można przy tym żywić żadnych wątpliwości, jaki element ma na myśli francuski tomista, skoro gdzie indziej wyraźnie podkreśla, że istnienie konstytuuje byt jako taki, byt jako realny ${ }^{44}$. Element ten (istnienie) musi być wszakże ujęty łącznie, a nie w oderwaniu od bytu: ,...le concept de l'existence ou de l'exister (esse), n'est pas et ne peut pas être „coupé” du concept absolument premier de l'être (ens, ce-qui est, ce-qui existe, ce-qui a pour acte d'exister) [...] Le concept de l'existence ne peut pas être visualisé complètement à part, détaché, isolé, séparé de celui de l'être..." ${ }^{45}$. Na następnej stronie Maritain zaznacza, że ujęcie samego istnienia powielałoby błąd oderwania się od bytu, jaki popełnia współczesny egzystencjalizm. Z przytoczonego tekstu wynika jednak wyraźnie, że francuski tomista, mówiąc o bycie, ma na myśli byt przygodny. W niniejszym artykule stale natomiast chodzi o uchwycenie w pojęciu bytu tego, co istotne dla bytu jako takiego. Dlatego możemy - pomijając zastrzeżenia

39 In I Sent., d. 38, q. 1, a. 3.

40 In Boreth. de Trinit., 5, 3, c.

41 J. Owens, St. Thomas and the Future of Metaphysics, Milwaukee 1957, 38.

42 Zoib. B. Bakies, Przedmiot afirmacji sadu egzystencjalnego, „Studia Philosophiae Christianae" 14 (1978) nr 1, 25-29.

43 Zob. J. Maritain, Sept leçons sur l'être et les premiers principes de la raison spéculative, 24.

44 Zob. tenże, Antimoderne, 180.

45 Tenże, Court traité de l'xistence et de l'existant, 45. 
Maritaina - podjąć myśl o zawarciu w pojęciu bytu jednego tylko elementu - istnienia.

Trzeba tutaj wrócić do problemu, w jaki sposób takie pojęcie bytu utworzyć. Czym innym bowiem jest wiedza o tym, że w zawartości pojęcia bytu należy ując wyłącznie istnienie, czym innym przedsitawienie procesu prowadzącego do utworzenia takiego pojęcia. Jak, mając w punkcie wyjścia do czynienia wyłącznie z bytami złożonymi, odkryć, że owo złożenie nie nalleży do natury bytu jako takiego? Jak, przed uzasadnieniem istnienia Boga, uzyskać wiedzę o tym, iż byt nie tylko nie musi być związany $z$ taką, czy inną formą ruchu, ale że może być niepodległy żadnej zmianie? ${ }^{46}$ Jak stwierdzić, że dla bycia bytem nie tylko nie jest konieczne istnieć $w$ tym, czy innym przedziale czassowym, ale że do natury bytu jako takiego należy absolutna bezczasowość? ${ }^{47}$ Słówko ,jakiś" - towarzyszące terminom: ruch, czas, treść - zawarte we wniosku separacji, zdaje się dla tejże separacji wyznaczyć nieprzekraczalną granicę.

Spróbujmy, dla osiągnięcia wyznaczonego celu, rozszerzyć proces separacji. Niemożność uzyskania transcendentalnego pojęcia bytu płynęła stąd, że przekroczenie każdej kategorii bytowania jest możliwe tylko wtedy, gdy wskaże się na jakiś istniejący byt, który do owej kategorii nie należy. Aby przekroczyć kategorię bytów przygodnych, trzeba „wskazać" na istniejący byt, nie będący bytem przygodnym. W związku z tym nasuwa się myśl, żeby - dokonując separacji - nie ograniczać się do istniejących bytów. Przeciwnie - wychodząc $\mathrm{z}$ danych $\mathrm{w}$ doświadiczeniu istniejących zespołów treści - rozszerzyć analizę także na byty możliwe. Zabieg polegałby na myślowej kombinatoryce, którą można, posługując się terminologią Husserla, nazwać uzmiennianiem danych. „Dane” w omawianym przypadku, to istniejące kompleksy treści, uzmiennianie polegałoby na myślowym tworzeniu dowolnych układów treści i ,przymierzaniu" ich do istnienia. Tu od razu powstaje problem, czy operowanie bytami możliwymi nie przekreśla realizmu metafizyki? Wydaje się, że nie musi to nastąpić. Trzeba się zgodzić z Garrigou-Lagrange'm, że intelekt może wydobyć (pomijając sprawę sposobu, w jaki — zdianiem tego myśliciela - to 'wydobycie następuje) byt $z$ różnych stanów, nie tylko

46 Byt może sprawiać ruch, ale do natury bytu jako takiego nie należy $\mathrm{z}$ konieczności zdolność bycia poruszanym. „Le plein savoir que l'être dépasse la mobilité, d'ailleurs, ne s'atteint pas sans une déduction telle qu'on en fait dans la démonstration de l'existence de Dieu. Ce n'est que lorsque nous connaissons qu'il existe au moins un être dans lequel il n'y a pas de puisisance passive ou de capacité à recevoir une nouvelle perfection que nous pouvons faire au sens plein le jugement de séparation qu'un être, pour qu'il soit un être, n'exige pas d'être sujet au mouvement'. (R. W. Schmidt, dz. cyt., 384 n.).

47 Zob. tamże, 386. 
aktualnego, lecz także możliwego istnienia, i. jest to byt realny ${ }^{48}$. Poszukujemy warunku bycia bytem. Wszystko, co ten warunek spełnia, jest bytem. Wszystko, co go może spełnić - nadaje się do bytowania. Dlatego w poszukiwaniu tego warunku można brać pod uwagę talkże byty możliwe. Nawet Krąpiec, jeden z tomistów najbardziej dbający o realizm metafizyki, rozciąga pojęcie bytu na byty realnie możliwe ${ }^{49}$. Takie rozszerzenie separacji wydaje się konieczne. Dla intuicyjnego dostrzeżenia, iż bytowość nie wiąże się z konieczności z żadnymi formami bytowania, nie wystarczy stwierdzić, że dla bycia bytem nie trzeba być ikssem, igrekiem, czy zetem, ale trzeba przebiec myślowo rozmaite możliwości bytowania. Zauważmy też, że wykryty warunek bycia bytem ma przecież dotyczyć nie tylko znanych kategorii bytowania, lecz także nieznanych, o ile te istnieją. Jeśli przyznaje się jednalk miano bytu istniejącym, choć nieznanym przedmiotom, to na tej samej zasadzie trzeba je przyznać nieistniejącym, lecz mogącym istnieć rzeczom.

Jak wyglądałby, w ogromnym skrócie, przebieg procesu tworzenia pojęcia bytu przy uwzględnieniu powyższego? W drugim etapie separacji, analizując zawartość sądów egzystencjalnych wydanych w pierwszym etapie (który pozostałby niezmieniony), na przykład: ,istnieje koń" i "istnieje ptak", stwierdzałoby się: do bycia bytem nie jest konieczne ani bycie koniem, ani bycie ptakiem - ponieważ może istnieć Pegaz. Racją uznania, że nie można ograniczać bytowania do kategorii ptaków i koni, jest tu możliwość istnienia bytu, który do owych kategorii mie należy. Skoro jest możliwe, aby isitniał byt nie będący koniem, to nie można twierdzić, że aby istnieć, trzeba być koniem. Na tym szczeblu proponowana metoda postępowania niczego nie wnosi, ponieważ do tego samego wyniku dochodzi się w „tradycyjnej” separacji. Jej przydatność okazuje się dopiero w punkcie, w którym zawodziła metoda uprzednio stosowana. Kontynuując $\mathrm{w}$ podany sposób przekraczanie kolejnych kategorii bytowych, unika się na przykład dyskusji, czy do utworzenia pojęcia bytu potrzebna jest znajomość istnienia bytów niematerialnych. Stwierdzamy bowiem: do bycia bytem nie jest konieczne być czymś materialnym, bo może istnieć coś niematerialnego. I wreszcie w kulminacyjnym punkcie operacji stwierdza się: do bycia bytem nie jest konieczne posiadanie jakiejkolwiek treści, ponieważ może istnieć byt, będący samym, czystym istnieniem. Zabieg prowadzi, jak widać, do utworzenia pojęcia bytu, w którego zawartość nie jest ujęta żadna treść. W trakcie osiągania tego celu orzekało się jednak, bez przeprowadzania odnośnej dyskusji, co jest możliwe, a co nie. Wskutek tego proponowany zabieg posiada ten manka-

48 Zob. R. Garrigou-Lagrange, Le réalisme du principe de finalité, Paris $1932,126$.

49 Zob. cytowany w przypisie 26 tekst Krapca. 
ment, że dopiero poprzedzenie go ontologią tego, co możliwe - może mu nadać prawomocność.

W celu uniknięcia zaznaczonej komplikacji można, dokonując kombinatoryki różnych układów treści, położyć nacisk na to, że nie da się wskazać takiego jej układu, który musiałby z konieczności istnieć. To jednak nie wystarcza, bowiem $\mathrm{z}$ powyższego wynika tylko, iż żaden układ treści nie jest konieczny dla bycia bytem. Nie wynika, że można być bytem nie posiadając żadnej treści. Jak wyeliminować zaczarowane słówko ,jakiś"? Sięgnijmy do św. Tomasza. Pisze on: „impossibile est materiam esse sine aliqua forma, tamen non est impossibile aliqua forma esse sine materia, forma enim in eo quod forma non habet dependentiam ad materiam" "50. Nie popełni się na pewno błędu, jeśli myśl Tomasza odniesie się do wszystkich elementów pozostających do siebie w stosunku możności i aktu, zatem także na istotę i istnienie. Wtedy można stwierdzić, że nie jest niemożliwe, aby jakieś istnienie nie było związane $z$ żadną istotą (i to bez konieczności konstruowania rozbudowanej teorii tego, co możliwe). Mamy zatem prawo orzec: nie tylko taka, czy innna, ale żadna treść nie jest potrzebna dla bycia bytem. Za zasadę bytu trzeba uznać to, bez czego nie może być bytu, a odrzucenie treści tej możliwości nie przekreśla. Treść stanowi tylko czynnik urealniany, znajduje się wyłącznie w rzeczach, które powstają, a nie są. Bez istnienia treść nie może przekroczyć granicy między nicością a bytowaniem. Istnienie jest jedynym czynnikiem, dzięki któremu coś jest realnym bytem. Natomiast istnienie wraz z treściami stanowią czynniki konieczne dla zaistnienia bytu przygodnego. Niestety, także ten sposób osiągnięcia transcendentalnego pojęcia bytu posiada tę niedogodność, że w trakcie rozważan trzeba założyć transcendentalny zasięg teorii aktu i możności.

Rysuje się jeszcze jedna droga mogąca doprowadzić do utworzenia pojęcia bytu. Zauważmy, że problem, który próbujemy rozwiązać, sprowadza się właściwie do następującego pytania: w jaki sposób można (poszukując warunków koniecznych istnienia czegokolwiek) wykroczyć poza pewną kategorię bytów, jeśli nie jest dana inna kategoria bytów? Taka przecież sytuacja zachodzi przy próbie przekroczenia kategorii bytów przygodnych. Wydaje się, że tylko wtedy (jeśli nie chcemy wprowadzać bytów możliwych), kiedy byty owej innej kategorii są racją istnienia bytów tej kategorii, którą chcemy przekroczyć. Na tę rację (jeśli - jak w naszym przypadku - w grę wchodzi kategoria bytów przygodnych) można wskazać wtedy, gdy dostrzeże się ograniczoność bytów kategorii danej. Czy zatem wskazanie na byt innej kategorii jako droga dojrzenia, że bycie bytem danej kategorii nie jest koniecznym warunkiem istnie-

${ }^{50}$ De ente et essentia, [w:] M. D. Roland-Gosselin, Le „De ente et essentia” de S. Thomas d'Aquin, Kain 1926, 33, 
nia czegoś - nie jest tożsame $\mathrm{z}$ dostrzeżeniem, że dla istnienia dowolnego przedmiotu danej kategorii konieczne jest istnienie Absolutu? Ale jeśli tak, to proces tworzenia pojęcia bytu jest tożsamy $\mathrm{z}$ argumentacją na istnienie Boga. Takie ujęcie musiałoby oczywiście pociągnąć za sobą zmianę struktury metafizyki. Prawie całą metafizykę trzeba by „pomieścić" w procesie tworzenia pojęcia bytu. Nie chodzi tu bowiem o rozszerzenie na całą metafizykę metody postępowania stosowanej w separacji, co było już niejednokrotnie postulowane. Projekt idzie w kierunku sprowadzenia całej metafizyki, a właściwie argumentacji na istnienie Boga ${ }^{51}$ do procesu separacji.

Niniejszy artykuł stanowi tylko sondaż problemu tworzenia pojęcia bytu. Wobec sytuacji, w której nie udało się dotychczas na terenie tomizmu egzystencjalnego zaprezentować sposobu utworzenia transcendentalnego pojęcia bytu, podano nasuwające się wstępnie próby rozwiązań zagadnienia. Trudności, jakie te rozwiązania posiadają, nie wydają się niepokonalne. O tym, czy któreś z nich okaże się przydatne, muszą zadecydować dalsze badania. Trzeba będzie uwzględnić $\mathrm{w}$ nich także analizy poczynione na temat tworzenia pojęcia bytu przez autorów do tomizmu egzystencjalnego nie należących.

\section{DER WERDEGANG DES „SEINS-BEGRIFFES” UND DAS PROBLEM DER EXISTENZ GOTTES}

\section{Zus a m menfassung}

Im allgemeinen stehen die Meinungen im Einklang dazu, dass der Begriff des Seins, der im existenziellen Tomismus gebraucht wird, soll unter anderen durch Transzendentalität geprägt sein d. h. er soll sich auf alle in irgendeine Weise existierende Seine beziehen.

In dem Aufsatz hat man den Prozess analysiert, der zur Prägung des SeinsBegriffes (sogenannter Separation) gefürt hat. Es hat sich ergeben, dass der Prozess nur zu solichem Seins-Begriff führt, dessen Designate ausschliesslich zufällige Seine sind. Dabei sicheint es, dass Separation tatsächlich nioht nur zur keinen Prägung von einem transzendentalen Seins-Begriff führt, sondern dass sie in der jetzigen Form zur solchen Prägung nicht zu führen vermag. In diesem Aufsatz hat man versucht, die Schwierligkeiten zu beseitigen, hat man ferner auf die Notwendigkeit hingewiesen, den Werdegang des Seins-Begriffes anders aufzufassen. Der Vorschlarg ist darauf gerichtet, diesen Prozess mit der Argumentation für Gattes Existenz gleichzusetzen. Selbstverständlich hätte das die Notwendigkei der Umgestaltung der Seins-Philosophie zu Folge.

51 Co prawie na jedno wychodzi. Jak wiadomo do uznania prawdziwości zdania „Bóg istnieje” dachodzi się w końcowych partiach filozofii bytu. Przy proponowanym tu kształcie metafizyki po utworzeniu pojęcia bytu (i uzasadnieniu istnienia Boga) nastepowałaby tylko teoria transcendentaliów. 